\title{
Extensional and magmatic nature of the Campbell Plateau and Great South Basin from deep crustal studies
}

\author{
J.W.G. Grobys ${ }^{\text {a, }}$, K. Gohl ${ }^{a}$, G. Uenzelmann-Neben ${ }^{\text {a }}$, B. Davy ${ }^{\text {b }}$, D. Barker ${ }^{\text {b }}$ \\ a Alfred Wegener Institute for Polar and Marine Research, PO BOX 120161, 27515 Bremerhaven, Germany \\ b GNS Science, 1 Fairview Drive, Avalon, Lower Hutt 5040, New Zealand
}

\section{A R T I C L E I N F O}

\section{Article history:}

Received 13 December 2006

Received in revised form 15 April 2008

Accepted 6 May 2008

Available online 13 May 2008

\section{Keywords:}

Rift zones

Ocean-bottom seismographs

Refraction methods

Crustal thinning

Campbell Plateau

Great South Basin

\begin{abstract}
A B S T R A C T
The Campbell Plateau is one of the largest submarine parts of the microcontinent of New Zealand. Although the opening of the Great South Basin played an important role in the late Gondwana break-up, the crustal structure of the basins and plateaus southeast of New Zealand are unknown to a large extent. Here we present results from a combined gravity, magnetic, multichannel seismic and seismic wide-angle reflection/ refraction transect across the Great South Basin and parts of the Campbell Plateau and interpret this on the basis of velocity distribution and crustal thickness. The lower crust exhibits a zone of southeastward increasing P-wave velocities $\left(v_{\mathrm{p}} \approx 7.1-7.4 \mathrm{~km} / \mathrm{s}\right.$ ) beneath the central Campbell Plateau. In this area, crustal thickness averages to $\sim 27 \mathrm{~km}$. We interpret this high-velocity zone as underplating beneath a previously extended crust. Our results hint that the extension of the Great South Basin was not accompanied by widespread magmatic activity, although signs of younger magmatism have been found across the Pukaki Rise and within the Great South Basin. Based on comparisons with nearby plateaus like the Lord Howe Rise and the Challenger Plateau, as well as probable paleo-positions of the magnetic anomaly systems of New Zealand and the Campbell Plateau, we suggest that an early phase of extension of the Campbell Plateau predated the opening of the Great South Basin.
\end{abstract}

(c) 2008 Elsevier B.V. All rights reserved.

\section{Introduction}

The Great South Basin (Fig. 1) is the product of Cretaceous extension between the Campbell Plateau and the South Island (Eagles et al., 2004) which led to accumulation of up to $8 \mathrm{~km}$ of sediments (Carter, 1988a). Syn-rift sediments were accumulated up to midCretaceous time and rapid subsidence began thereafter (Beggs, 1993; Cook et al., 1999). The Campbell Plateau (Fig. 1) is a continental plateau (Davey, 1977) that lies mostly at less than $1000 \mathrm{~m}$ beneath sea level, rising up to $500 \mathrm{~m}$ at the Pukaki Rise and emerges at the Auckland and Campbell Islands.

The documented timing of the break-up of New Zealand from Antarctica and of the opening of the Great South Basin (Cook et al., 1999; Eagles et al., 2004) leaves a number of open questions. Gravity and bathymetry of the Campbell Plateau indicate a crustal thickness that is significantly reduced compared to regular continental crust. The tectonic processes leading to the extension of the Campbell Plateau are unknown, but it has been suggested that this extension

\footnotetext{
* Corresponding author. RWE-Dea AG, Überseering 40, 22297 Hamburg, Germany. Tel.: +49 4714831 1361; fax: +494714831 1271 .

E-mail address: Jan.Grobys@rwe.com (J.W.G. Grobys).
}

was related to an Early Cretaceous extensional event or alternatively to the final break-up of New Zealand from Antarctica in the Late Cretaceous. Understanding these processes and their timing are important because they may explain the evolutionary history of some of the comparable plateaus in this region, e.g. the Lord Howe Rise and Challenger Plateau. Whether the Campbell Plateau underwent extension at the time of the extension of the Bounty Trough and Great South Basin or earlier is a subject of debate (Davey and Christoffel, 1978; Sutherland, 1999). Similarly, various hypotheses exist about the origins of and the relationship between the two major magnetic anomaly systems over the plateau, the Stokes Magnetic Anomaly System (SMAS) and the Campbell Magnetic Anomaly System (CMAS). It is still unclear, for example, if both anomaly systems are equivalents that have been offset by dextral strike-slip movement (Davey and Christoffel, 1978; Sutherland, 1999).

In order to investigate the mechanisms of Campbell Plateau extension and its role in the early opening of the southwest Pacific, the Alfred Wegener Institute for Polar and Marine Research (AWI) and GNS Science jointly conducted deep crustal seismic and potential field experiments across the Campbell Plateau, the Great South Basin and the Bounty Trough during R/V Sonne cruise SO-169 in 2003 (project name: (AMP). This paper deals with the combined gravity, magnetic, multichannel seismic reflection (MCS), and the refraction/wide-angle reflection seismic transect of profiles AWI-20030001 and coincident AWI-20030013 running northwest-southeast across the Great South 


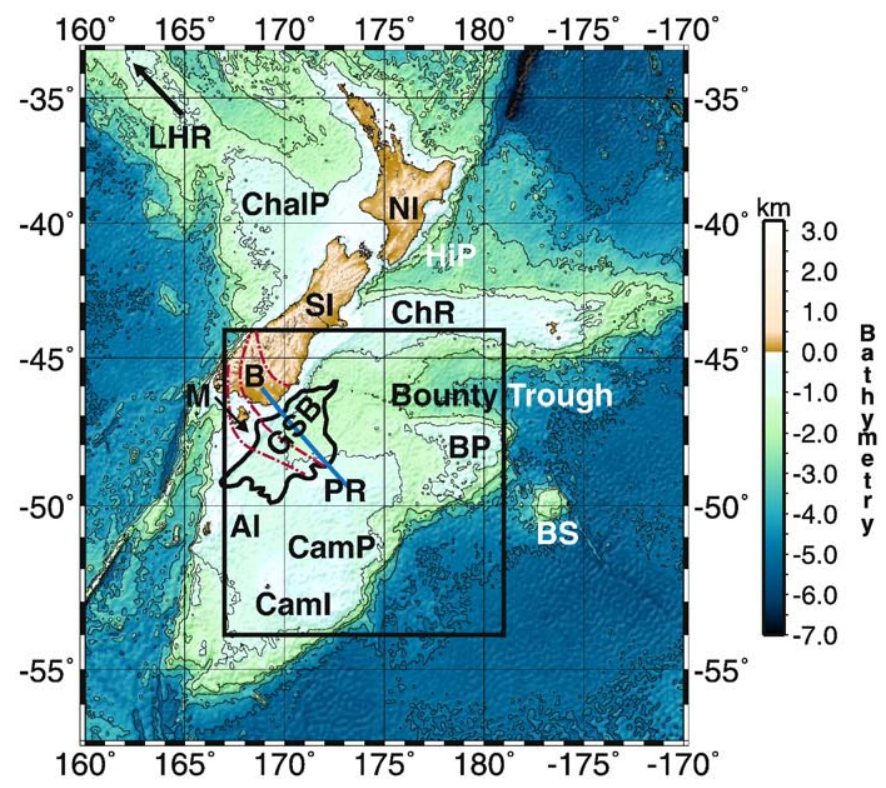

Fig. 1. Bathymetric overview map (Smith and Sandwell, 1997) of New Zealand and location of the CAMP experiment, showing AWI-20030001 and coincident AWI20030013 across the Bounty Trough (red). The black box shows the area of the gravimetric map (Fig. 3). Region $\mathrm{M}$ is Median Batholith and tentative seaward continuation after Cook et al. (1999), B are Caples/Brook St/Maitai/Murihiku Terranes in southern South Island. Abbreviations are: NI - North Island of New Zealand, SI South Island of New Zealand, AI - Auckland Islands, BP - Bounty Platform, BS - Bollons Seamounts, CamI - Campbell Islands, CamP - Campbell Plateau, ChalP - Challenger Plateau, ChR - Chatham Rise, GSB - Great South Basin, HiP - Hikurangi Plateau, LHR Lord Howe Rise, PR - Pukaki Rise. (For interpretation of the references to color in this figure legend, the reader is referred to the web version of this article.)

Basin and the northwestern part of the Campbell Plateau up to the Pukaki Rise.

\section{Geological setting}

\subsection{Overview and general crustal structure}

The Great South Basin is the largest and deepest sedimentary basin on the Campbell Plateau, New Zealand, encompassing an area of $\sim 85,000 \mathrm{~km}^{2}$. The basin itself is not obvious in the bathymetry, but can be defined by the $2000 \mathrm{~m}$ sediment thickness isopach (Cook et al., 1999). It is separated by basement highs from the Canterbury Basin to the north and from the Pukaki Basin to the south. Cook et al. (1999) interpreted the basement to consist of Cretaceous rocks, but they did not rule out the possible presence of older rocks or metamorphosed sediments beneath the Urutarawan sediments (106.4-103.3 Ma) (Fig. 2). Where the basement rocks have been drilled, they have been recognised as schists of Triassic to Jurassic ages, or granitic rocks of Cretaceous origin (Cook et al., 1999 and references therein). Evidence for Cenozoic volcanism has been found in various clusters widely scattered over the Great South Basin and the Campbell Plateau. Although Farrar and Dixon (1984) suggested a time-dependent migration of volcanic activity over the Campbell Plateau, new ${ }^{40} \mathrm{Ar} /$

${ }^{39} \mathrm{Ar}$ ages combined with published ages do not show any correlation of age with location (Hoernle et al., 2006).

Gravity modelling by Cook et al. (1999) suggests a minimum thickness of the crystalline crust of $10-15 \mathrm{~km}$ in the central Great South Basin. The same gravity models indicate a maximum thickness of about $29 \mathrm{~km}$ beneath the southeastern tip of the South Island and beneath the central Campbell Plateau. An assumed initial thickness of the crystalline crust of $\sim 35 \mathrm{~km}$ implies stretching factors of about 2-3 (Cook et al., 1999).

\subsection{Terranes of the Great South Basin}

The Great South Basin covers several of the Eastern and Western Province terranes which are divided by the Median Batholith (Mortimer et al., 1999) (Fig. 1). This is a suite of plutons with the oldest of latest Permian age and the youngest of Cretaceous age. The Median Batholith coincides spatially with a major suture zone (Davey, 2005) most probably of Middle-Late Triassic time (Mortimer et al., 1999; Davey, 2005). Additionally, the large strike-slip plate boundary of the Alpine Fault crosses the terranes and offsets their parts by several hundreds of kilometers. Eastern Province terranes are either island arc (Maitai Terrane, Brook Street Terrane) crust or comprise subduction related metasediments (Rakaia Terrane, Caples Terrane, Murihiku Terrane) (Mortimer et al., 1999). They are interpreted to have been accreted during subduction at the Gondwana margin since Triassic times. The Western Province is interpreted to be part of the continental crust of Gondwana of Cambrian to Devonian times, influenced by extensive plutonism (Cooper and Tulloch, 1992). Takaka Terrane consists of metasediments derived from island arcs, Buller Terrane rocks are metasediments of the Greenland Group (Cooper, 1989).

\subsection{Nature of the magnetic anomaly systems}

Ship- and airborne magnetic data collected over the South Island and the Campbell Plateau define two magnetic anomaly systems (Fig. 3). The SMAS with its northernmost component, the Junction Magnetic Anomaly (JMA), can be traced across the southern South Island and into the Great South Basin, where it decreases in amplitude and vanishes (Hunt, 1978; Sutherland, 1999). The southwestern part of the SMAS is attributed to plutonic complexes of the Median Tectonic Zone (Kimbrough et al., 1994), while the northern part, the JMA, marks the contact between the Caples and Maitai terranes (Cook et al., 1999). The central anomaly of the SMAS is attributed to a source at moderate depths that underlies or intrudes the Murihiku Terrane greywackes (Mortimer et al., 2002). Cook et al. (1999) explain this body either as an old magnetic basement of at least Permian age or as a syn- or post-Murihiku (Jurassic) intrusion.

Further south, a zone of high-amplitude positive magnetic anomalies trends northeast across the central Campbell Plateau (Fig. 3). This anomaly, the Campbell Magnetic Anomaly System, is

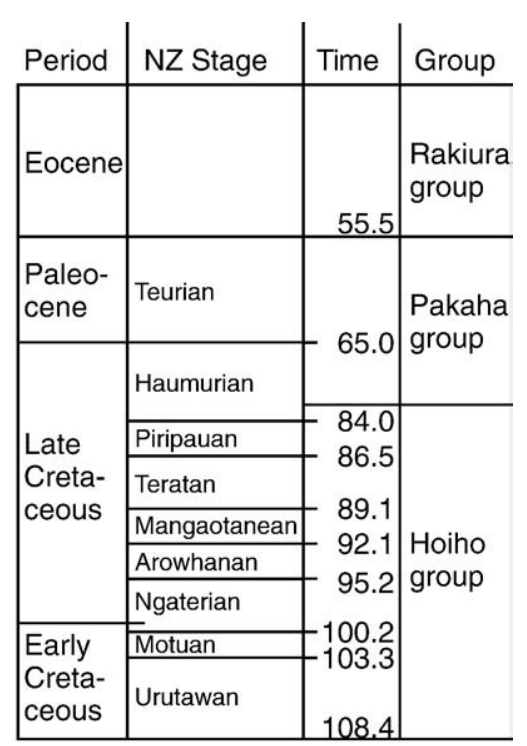

Fig. 2. Excerpt from stratigraphic timescale of New Zealand from Early Cretaceous to Eocene after Cooper (2004). Width of bars representing the ages is not to scale. 


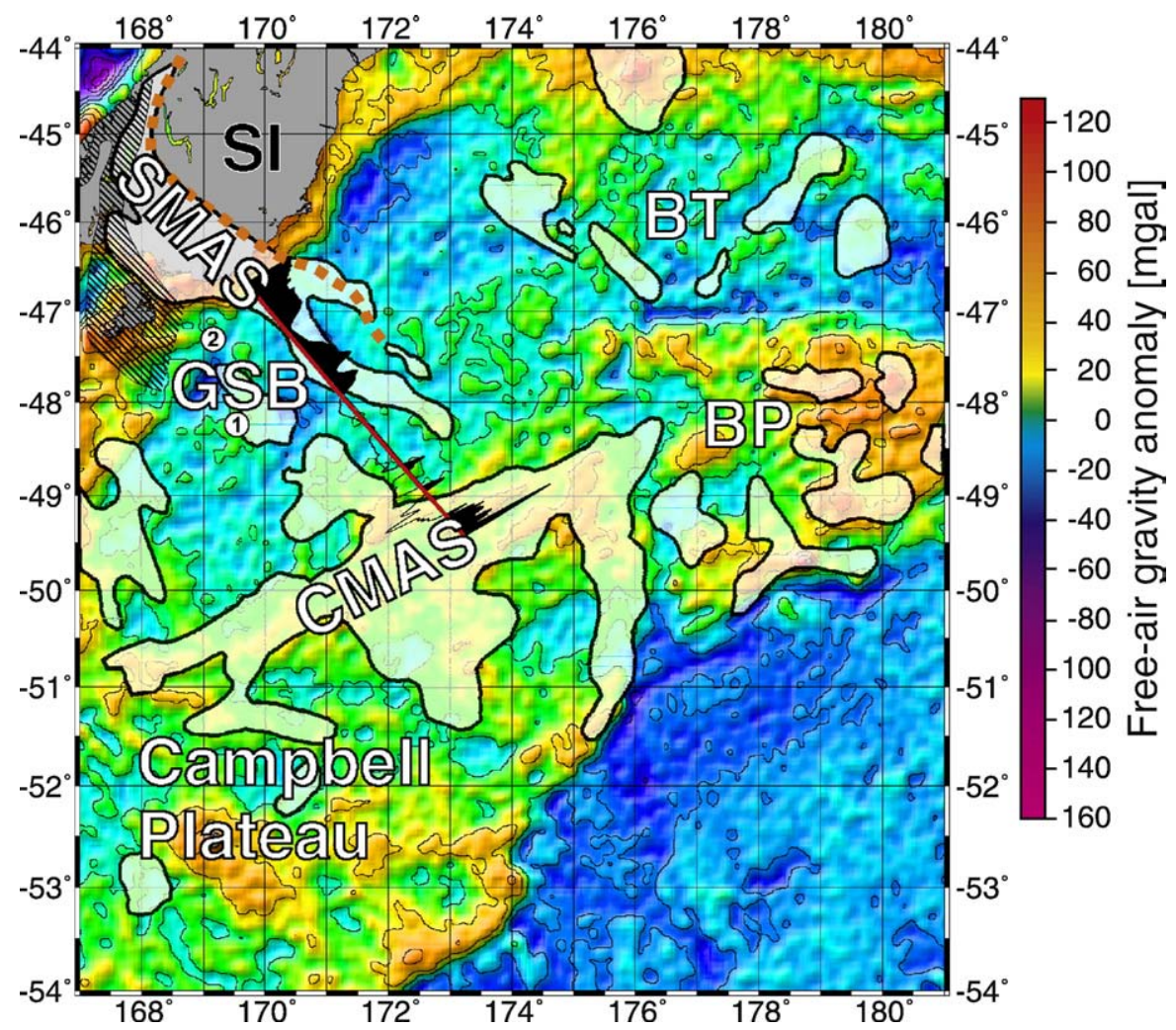

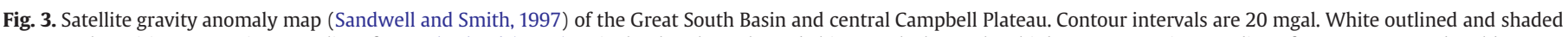

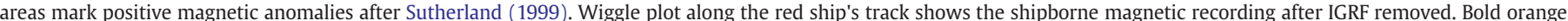

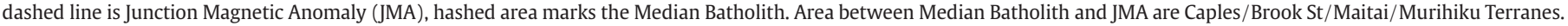

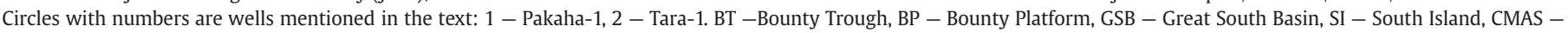

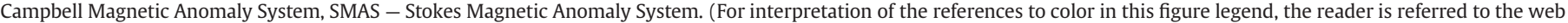
version of this article.)

interpreted to be caused by magnetic basement rocks (Davey and Christoffel, 1978). They postulated that the CMAS was originally a continuation of the SMAS, which is now offset by a major shear zone. Later plate-tectonic reconstructions (Kamp, 1986) estimated this offset to about $330 \mathrm{~km}$, a value that approximates the amount of extension in the Bounty Trough estimated by Kamp. A more recent plate-tectonic reconstruction (Grobys et al., 2008) estimates the extension in the Bounty Trough to $\sim 75-100 \mathrm{~km}$.

\subsubsection{Stratigraphy}

A well-preserved stratigraphy of up to $8 \mathrm{~km}$ thick sediments down to the basement makes it possible to date the opening of the Great South Basin. The stratigraphy based on an extensive seismic dataset (Cook et al., 1999) is also tied to eight well logs (Cook et al., 1999). Sediments of the Hoiho group (108.4-83.5 Ma) (Fig. 2) lie above the interpreted basement. These sediments are heavily faulted along SWNE trends and laterally discontinuous. The deposition took place in faulted depressions and sub-basins, suggesting syn-rift sedimentation. Piripauan (86.5-84.0 Ma) sediments show the beginning of a marine influence, and indicate that the basin's subsidence began at this time (Cook et al., 1999).

The Pakaha group sediments (83.5-55.5 Ma) contain relatively little evidence for continuous faulting. They are interpreted as having been deposited after normal faulting had ceased and during rapid subsidence of the basin. Cook et al. (1999) estimate a maximum of $1600 \mathrm{~m}$ syn-rift subsidence and $2200 \mathrm{~m}$ post-rift subsidence took place (Cook et al., 1999). Eocene sediments of the Rakiura group (55.5-34.3 Ma) mark the transition to open ocean conditions. In summary, this stratigraphic information contains the timing of the opening of the Great South Basin to have ceased in Piripauan time (86.5-84 Ma).

\section{Data acquisition, processing, and description}

Seismic line AWI-20030001 of the CAMP Experiment is a $510 \mathrm{~km}$ long NW-SE-trending transect across the Great South Basin extending for $\sim 85 \mathrm{~km}$ onshore (Fig. 1). The transect runs from the Pukaki Rise in the South to the vicinity of Gore, South Island. We acquired a coincident refraction/wide-angle reflection and multichannel seismic (MCS) dataset (Fig. 3) as well as magnetic and gravity data along the offshore part of this line. Bathymetry along the profile was recorded with the R/V Sonne's SIMRAD® EM-120 and Parasound systems.

\subsection{Seismic reflection}

For the MCS, the receiver array was a single $2150 \mathrm{~m}$ long streamer. A source array of six G-Guns ${ }^{\circledR}$ with a total volume of $481\left(2980 \mathrm{in}^{3}\right)$ generated the signals. Approximate shot spacing was $50 \mathrm{~m}$. Multichannel seismic data of profile AWI-20030013 were processed in a standard processing sequence comprising sorting ( $25 \mathrm{~m}$ CDP interval), a detailed velocity analysis (every $50 \mathrm{CDPs}$ ), multiple suppression via a Radon transform, spike deconvolution to remove the bubble effect, corrections for spherical divergence and normal moveout, residual static corrections, stacking, and post-stack time migration.

The seismic reflection data show an up to $7000 \mathrm{~m}$ thick fill of generally well-stratified layers over the Great South Basin (Fig. 4). A channel can be identified as deep as ca. $2 \mathrm{~km}$ below the seafloor (b.s.f.). It has migrated $20 \mathrm{~km}$ southeastwards in the period from Late Eocene to 


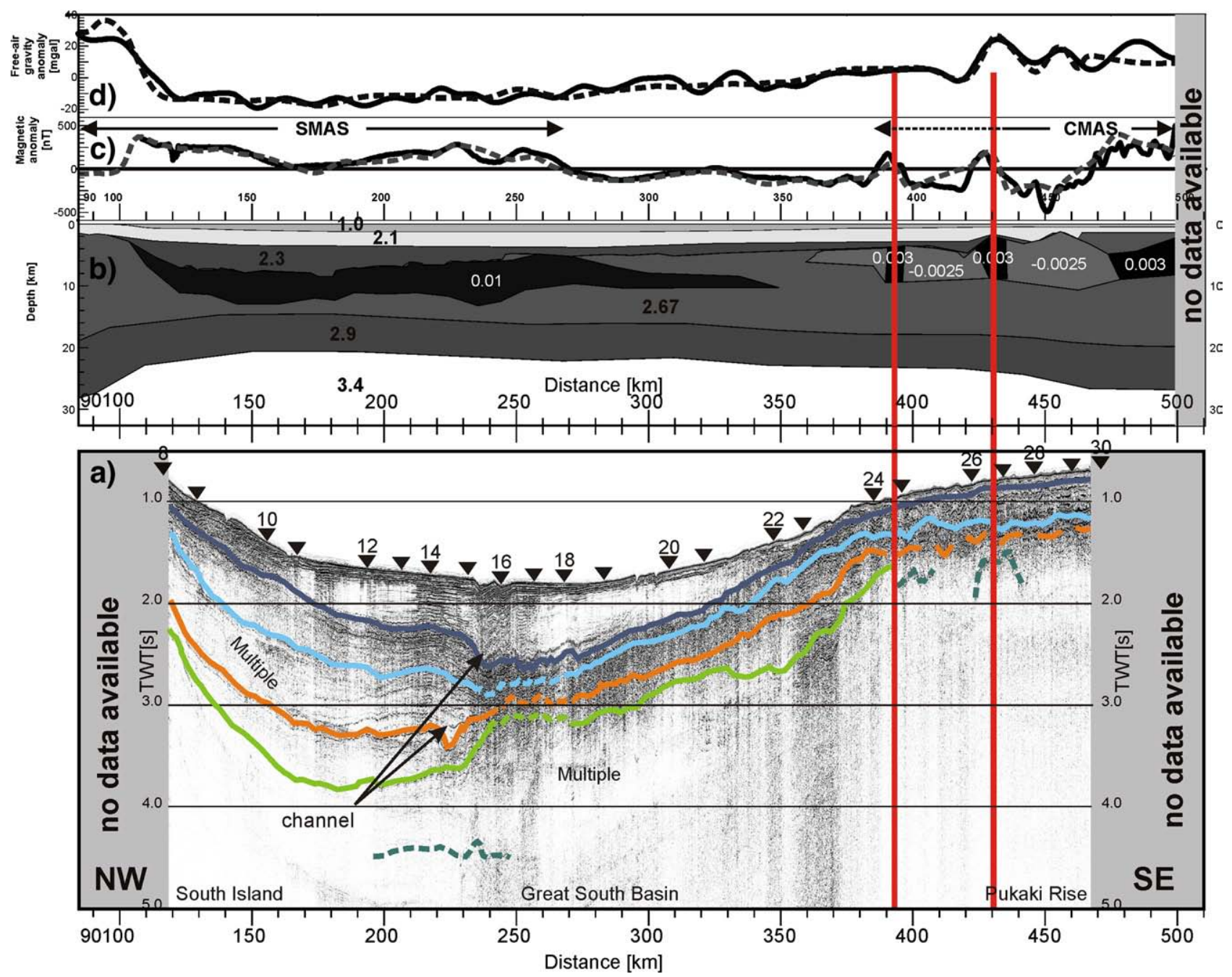

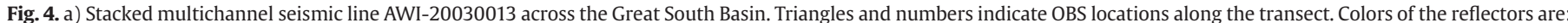

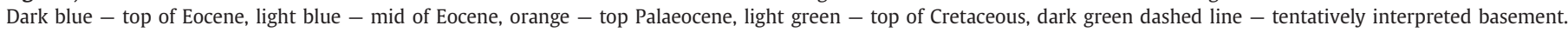

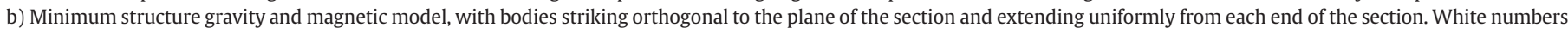

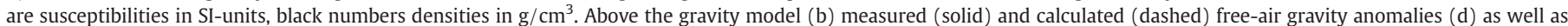

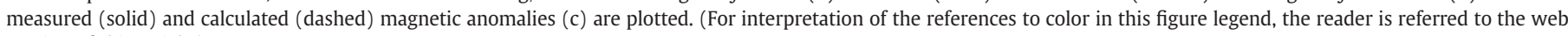
version of this article.)

late Paleocene $(\sim 20 \mathrm{Ma})$. The channel's northern levee is well developed, the southern levee is $\sim 100 \mathrm{~m}$ thinner. A distinct unconformity cuts across the levee sediments, above which the channel starts to fill. Basement can be tentatively traced at a depth of $\sim 350 \mathrm{~m}$ (b.s.f.) in the southeast. Only patches of basement can be observed anywhere else along the profile. By comparison with the Hunt lines B-210, B-214 and F14 (Cook et al., 1999), we were able to correlate four main reflectors from the top of Cretaceous, top of Palaeocene, top of mid Eocene and top of Late Eocene. Between 200 and $250 \mathrm{~km}$, the reflection patterns change. Layers are well-stratified northwest and southeast of this area, whereas the layering is hummockier in between. Northwest of the channel, which abuts this hummocky region, Paleocene reflections continue with high amplitude and moderate continuity in a more chaotic pattern. However, reflections can be traced up onto the Pukaki Rise. No intrabasement reflector or Moho reflection can be observed anywhere on profile AWI-20030013.

\subsection{Seismic refraction}

The wide-angle reflection/refraction line was shot with a VLF airgun array of 20 airguns with a total volume $521\left(3240 \mathrm{in}^{3}\right)$ at an average shot interval of $150 \mathrm{~m}$. Twenty ocean-bottom seismometers, 4 ocean-bottom hydrophone systems (OBS of GEOPRO ${ }^{\circledR}$ and University of Hamburg type, OBH of GEOMAR type), and 6 seismic land stations recorded the shots of the seismic array. OBS/OBH stations were placed at intervals between 13.5 and $27 \mathrm{~km}$, onshore stations were placed irregularly at intervals from 7 to $39 \mathrm{~km}$. We converted the OBS/OBH data to SEGY format and applied corrections for the drift of the OBS/ $\mathrm{OBH}$ clock. Exact OBS/OBH positions along track at the seafloor were relocated using direct wave arrivals. The maximum horizontal distance between an OBS/OBH deployment location and its position on the seafloor was $384 \mathrm{~m}$.

To enhance signal-to-noise ratio and resolution, the data were filtered with a time and offset dependent band-pass filter, deconvolved with a spiking deconvolution at an operator length of $200 \mathrm{~ms}$, and FK-filtered at large-offset ranges to suppress wrap-around noise from previous shots. After each of these processing stages, we picked seismic phases. The resulting picks were carefully compared with each other, in order to exclude phase-shifts caused by any of the three processing steps at the highest signal-to-noise ratio.

The vertical components show coherent P-wave phases at up to $100 \mathrm{~km}$ offset (Figs. 5 and 6). The signal-to-noise ratio differs strongly 


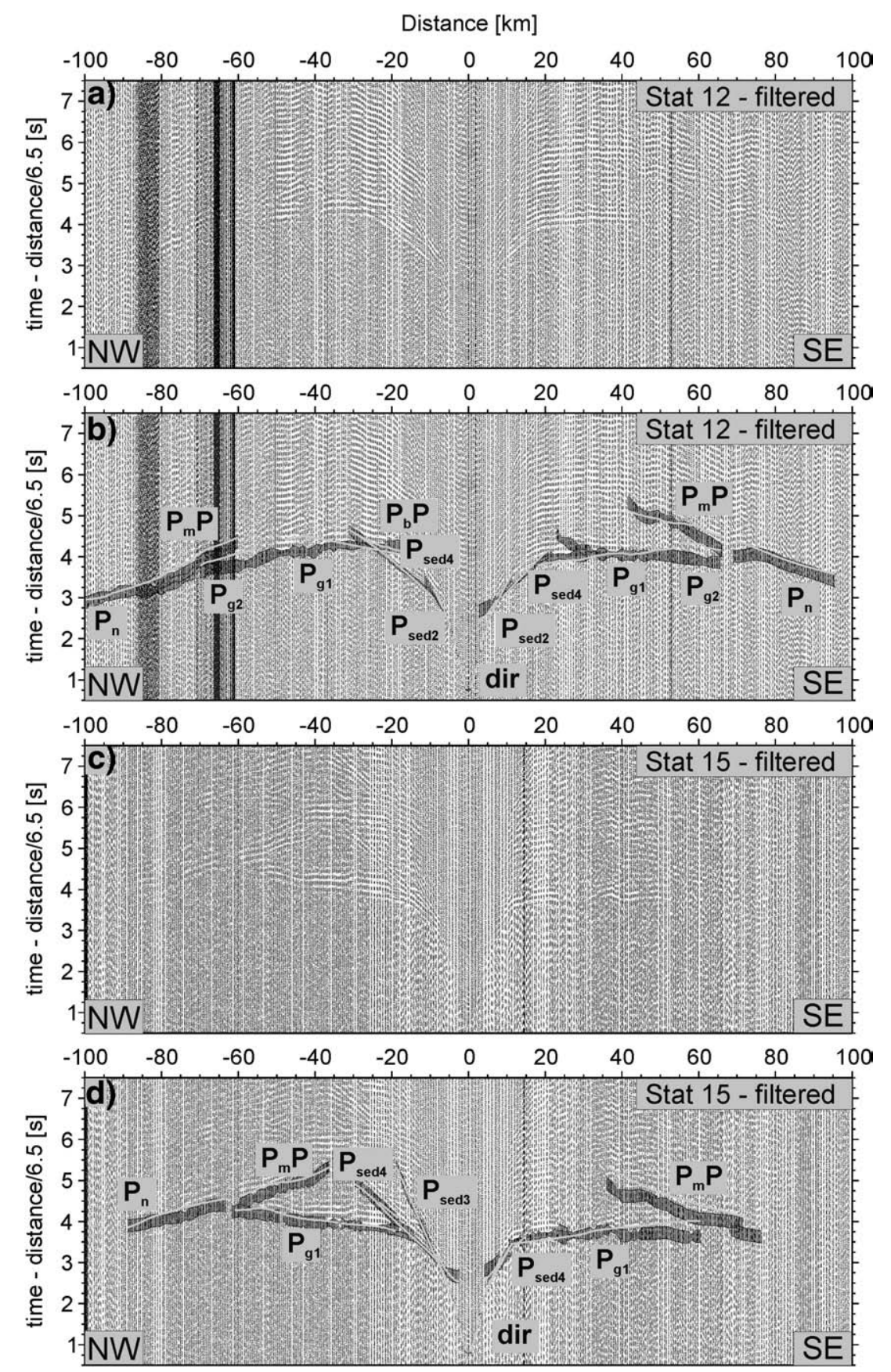

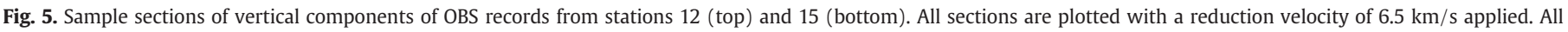

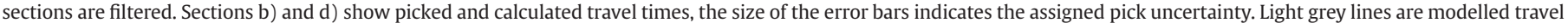
times. $\mathrm{P}_{\mathrm{C}} \mathrm{P}-$ reflections from the mid-crustal reflector, $\mathrm{P}_{\mathrm{b}} \mathrm{P}-$ reflections from the basement.

from one station to another. Weak S-wave phases can be seen at short offsets in the horizontal components of a few OBS/OBH recordings only. Most P-wave sections (Fig. 5) show high-amplitude wide-angle reflections from the Moho $\left(\mathrm{P}_{\mathrm{m}} \mathrm{P}\right)$. In addition to the inner part of the Great South Basin, weak wide-angle reflections from the basement $\left(\mathrm{P}_{\mathrm{b}} \mathrm{P}\right)$ as well as intra-crustal wide-angle reflections $\left(\mathrm{P}_{\mathrm{c}} \mathrm{P}\right)$ can be observed (for picking statistics see Section 5).

We identified refraction arrivals from three to four sedimentary layers $\left(\mathrm{P}_{\text {sed } 1}-\mathrm{P}_{\text {sed } 4}\right)$, and two crustal layers $\left(\mathrm{P}_{\mathrm{g} 1}, \mathrm{P}_{\mathrm{g} 2}\right)$. A separation into different sedimentary phases was feasible due to strong first order velocity discontinuities and laterally homogeneous apparent velocities within the layer, whereas a moderate signal-to-noise ratio did not enable an exact separation of the two crustal refractions. We observed weak $P_{n}$ phases (refractions within the uppermost mantle) (Figs. 5 and 6) on some of the OBS records within the basin and on the Pukaki Rise.

\subsection{Potential field data}

We obtained free-air gravity anomalies from a shipboard LaCoste \& Romberg S-80 gravimeter recorded at 1 -second intervals. The measured values collected by the gravimeter are tied to the N.Z. Potsdam system (1959) via the gravity base station in Lyttleton, New Zealand.

The gravity anomaly pattern (Fig. 4) principally represents the bathymetry of the Great South Basin and the Pukaki Rise/central 
Campbell Plateau as well as the crustal thinning beneath the Great South Basin (Fig. 4). Over the Campbell Plateau, a set of three anomalies of short-wavelength $(\sim 20 \mathrm{~km})$ and $\sim 30$ mgal amplitude can be seen.
Magnetic data were recorded by a Geometrics G-801 proton precession magnetometer towed $\sim 150 \mathrm{~m}$ behind the ship. The magnetic anomaly values were calculated by subtracting the IGRF a)
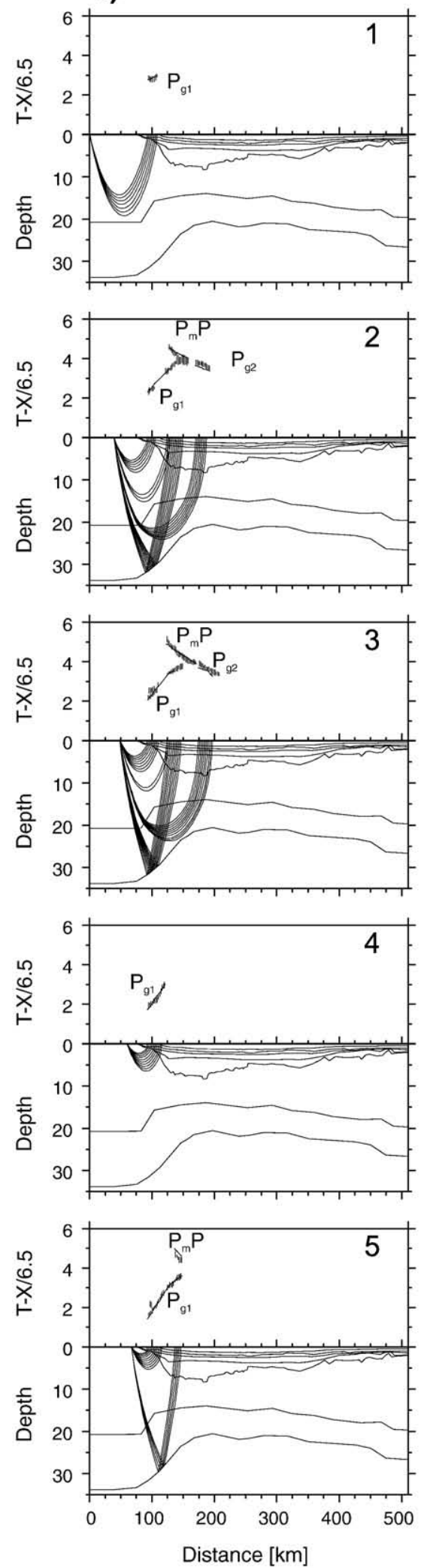
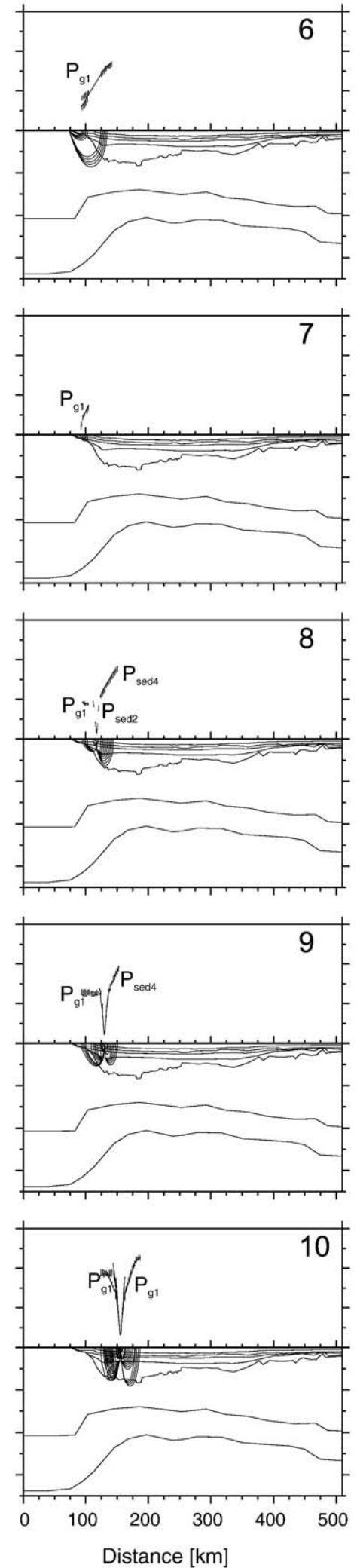
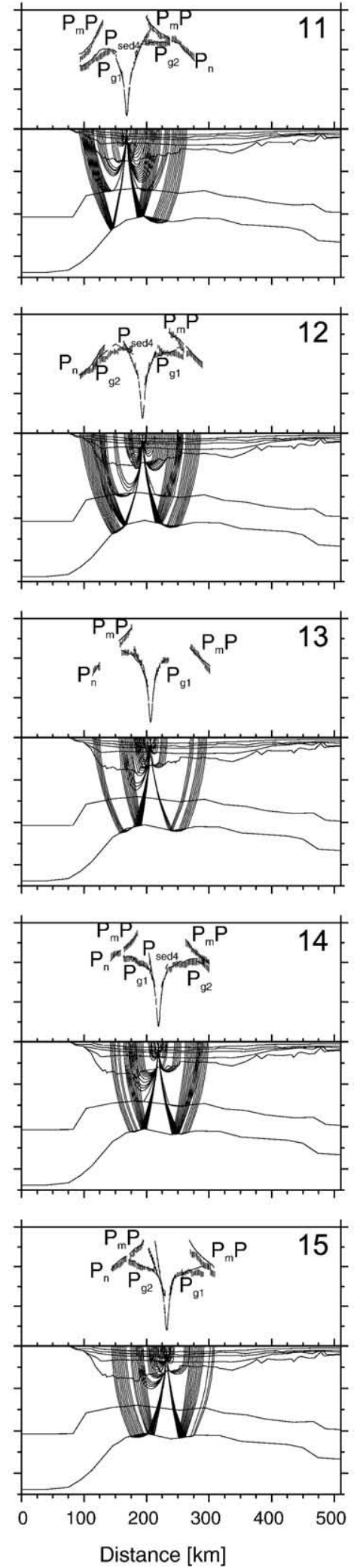

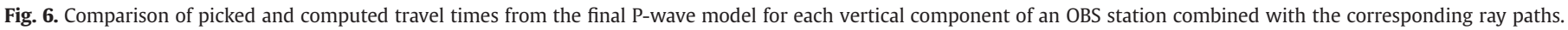

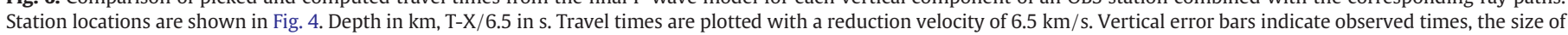
the bars corresponds to the assigned pick uncertainty. Calculated travel times are solid lines. Near-offset phases (Psed1-3, direct wave) are not labelled. 
b)
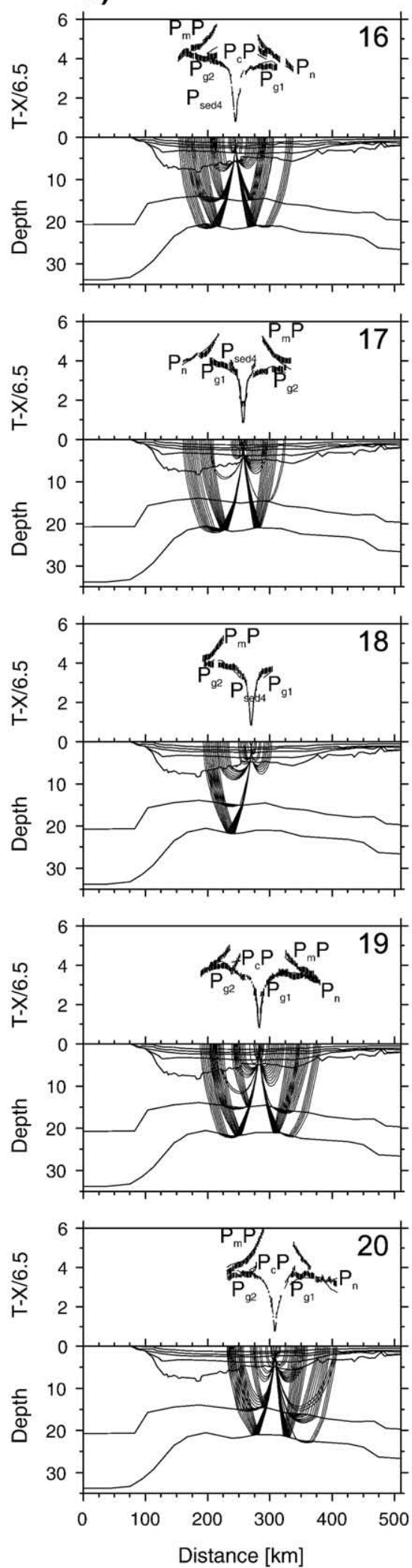
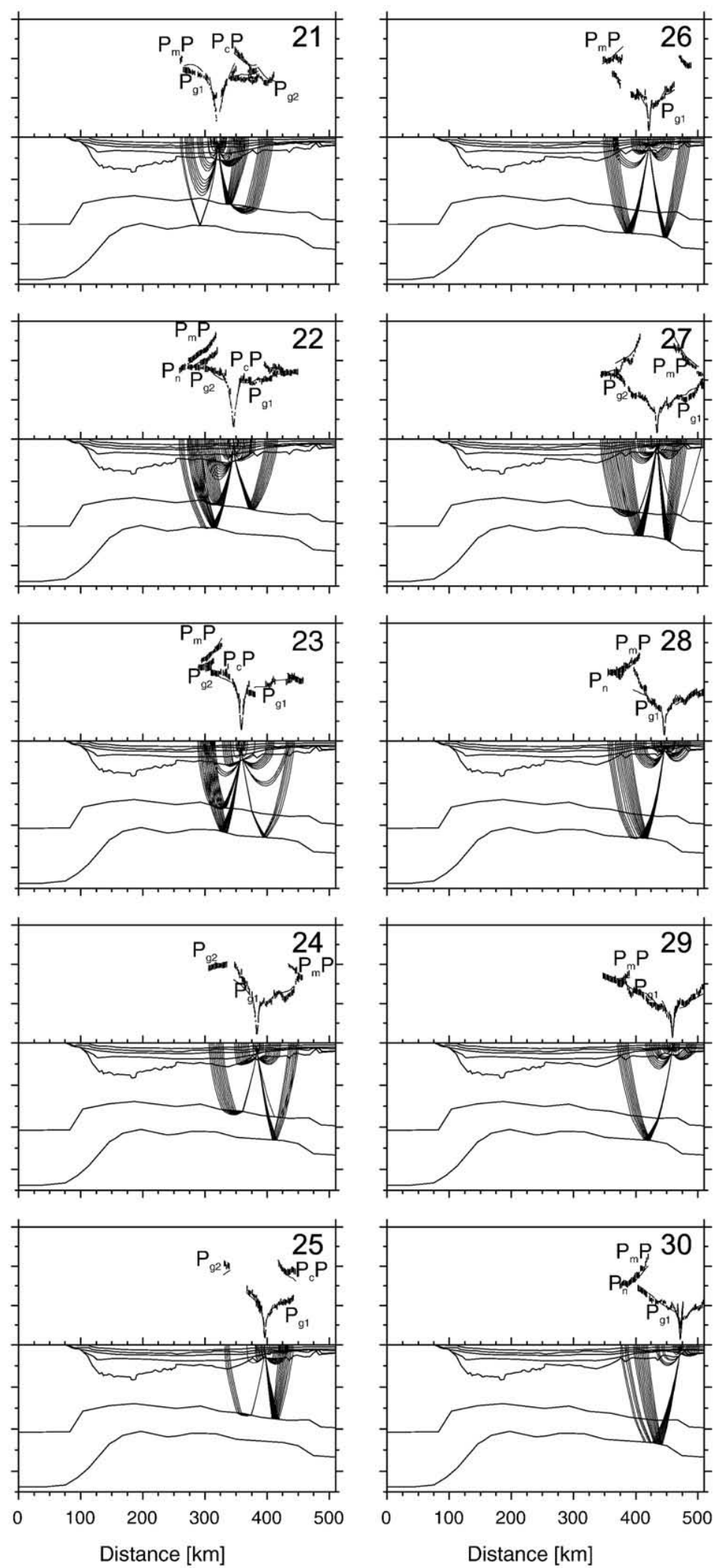

Fig. 6 (continued)

reference field from the observed total field measurements. The magnetic anomaly pattern shows a long-wavelength pattern $(\sim 150 \mathrm{~km})$ of $\sim 200 \mathrm{nT}$ amplitude across the Great South Basin, a set two magnetic anomalies of $400 \mathrm{nT}$ amplitude and wavelengths of $\sim 15-$ $20 \mathrm{~km}$ near the Pukaki Rise, and several anomalies of short-wavelength $(\sim 2 \mathrm{~km})$ and low amplitude (80-100 nT) at the Pukaki Rise. 


\section{Modelling}

\subsection{Seismic travel-time modelling}

We applied a layer-stripping procedure to refine the velocitydepth model by forward modelling. The forward modelling was followed by a travel-time inversion (Zelt and Smith, 1992), using all Pwave reflected and refracted phases. At this stage we only allowed positive velocity gradients except for one high-velocity lens in one sedimentary layer. As only very few shallow wide-angle reflections can be seen in the data and basement was only visible in patches in the MCS data, the top of basement beneath the Great South Basin was modeled using the well-constrained depth-to-basement map of Cook et al. (1999). Their basement map is based on gravity modeling constrained by a dense net of seismic lines with a higher accuracy as an inversion could provide. Only the basement at the Pukaki Rise was inverted. However, in this region, the control on the top of basement is only poor to moderate. We introduced another velocity interface (Fig. 7) into the middle crust of the model. This interface provides a change in the velocity gradient and is constrained by wide-angle reflections in the southeastern part of the profile.

While the resolution of the velocity-depth model (Fig. 8) can be calculated within the inversion scheme (Zelt, 1999), it is more difficult to quantify errors in phase identification and discrimination. Therefore, we set the variable pick uncertainties in the range $40 \mathrm{~ms}$ to $150 \mathrm{~ms}$ depending on the signal-to-noise ratio. Although the true pick uncertainty might be lower than the assigned pick uncertainty, an uncertainty in correct phase identification is included with this value (Berndt et al., 2001).

The travel-time inversion process helps assess the model quality as it calculates rms-errors, model-based travel times and Chi-squared values for each branch of the travel-time curves (Table 1). With the uncertainties presented above we calculated travel-time residuals and normalised Chi-squared values. These values accompanied by the number of picks are presented in Table 1 . The overall rms-misfit is $0.160 \mathrm{~s}$ with a normalised Chi-squared value of 2.113 , which is close to the optimum of 1 . In general, the rms-misfits and Chi-squared values are significantly smaller in the northwestern part of the profile than in the southeast, because the southeastern end of the profile exhibits very rough basement and disturbed reflectors. Some of the larger misfits (e.g. near the Pukaki Rise) seem to be caused by a complicated shallow structure. Thus, forcing smaller Chi-squared values would lead to a rough model in areas where data quality does not allow a better resolution of velocities.

Fig. 8 presents the values of the main diagonal of the resolution matrix of the velocity nodes of the P-wave velocity-depth model. Maximum resolution is represented by a value of 1 . Smaller values denote a spatial averaging of the true earth by a linear combination of model parameters (Zelt, 1999). Resolution matrix values greater than 0.5 indicate well resolved nodes. Our P-wave model is best resolved (Fig. 8) in the upper and lower crust over the Great South Basin and parts of the Pukaki Rise, where the resolution values lie well above 0.8 . Ray coverage is densest in this region. As more rays turn in the upper part of a layer, this part is generally better resolved than the lower part of the same layer. The resolution for the uppermost mantle in the central part of the model is good $(0.6-0.8)$. No $P_{n}$ phases were recorded from beneath the South Island due to a change in the topography of the Moho and limited source-receiver offsets. Many regions of the velocity model are less resolved for the sediment layers. Due to smaller offset ranges and the masking effect of high-amplitude direct wave arrivals (White and Matthews, 1980), upper parts of the model are less covered with overlapping rays. Structural uncertainties in the upper layers are reduced by reference to the coincident MCS line. The Moho and the mid-crustal layer boundary are well resolved in the middle of the profile. Between 323 and $390 \mathrm{~km}$, the mid-crustal layer boundary has resolutions greater than 0.65 , between 196 and $449 \mathrm{~km}$, northwest of $196 \mathrm{~km}$, the mid-crustal layer boundary only provides a change in the velocity gradient. The Moho has resolution values greater than 0.65 .

\subsection{Gravity modelling}

The upper basement surface above the $2670 \mathrm{~kg} / \mathrm{m}^{3}$ body in the gravity model is been constrained along its northwestern half using the basement surface from Cook et al. (1999). This latter surface was derived by interpreting all publicly available seismic reflection which was in turn tied to existing well data. Basement is tied at the southeastern limit of the model to nearby surface exposures interpreted on regional seismic reflection data. The basement surface was interpolated between these constraints.

The crustal thickness in the gravity models is only loosely constrained at either end of the model apart from the seismic model
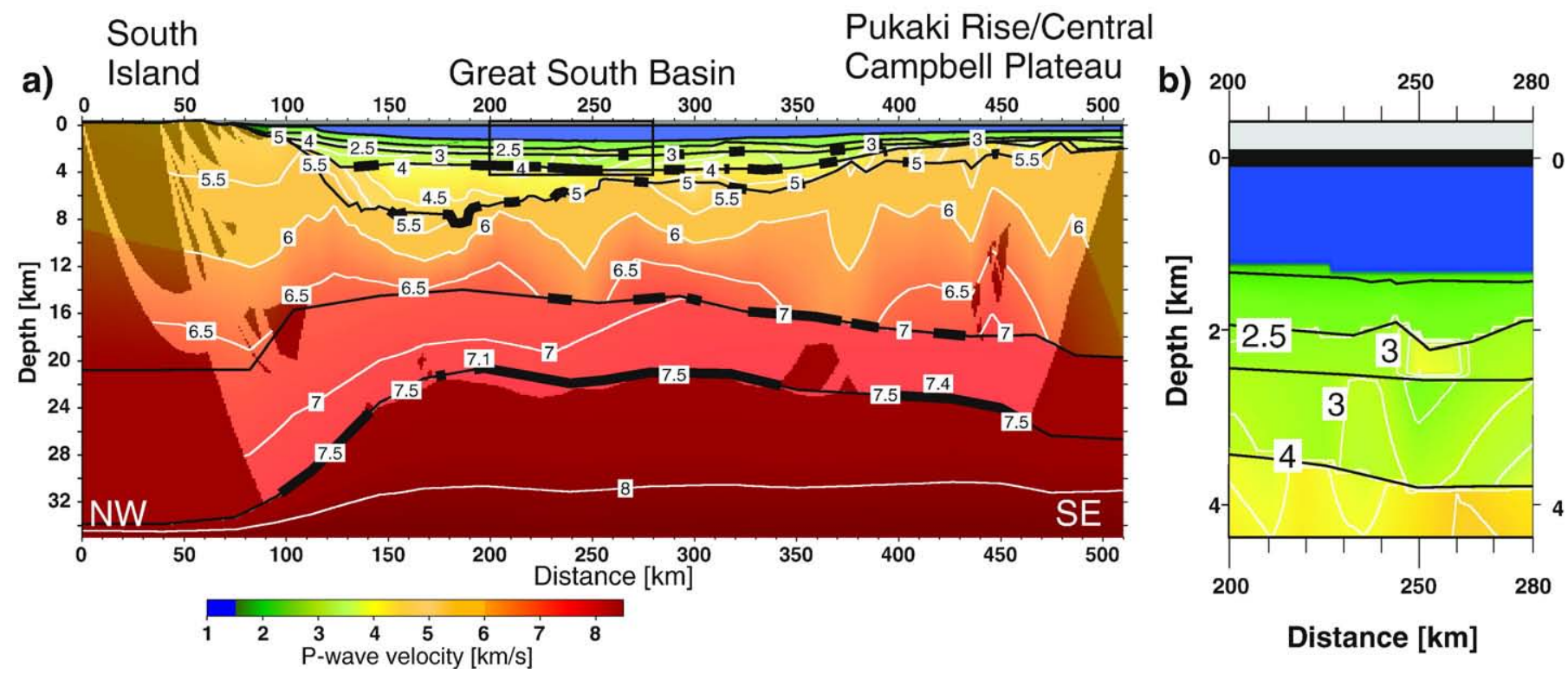

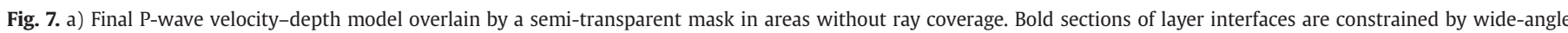
reflections. b) Zoom in the low velocity zone. 


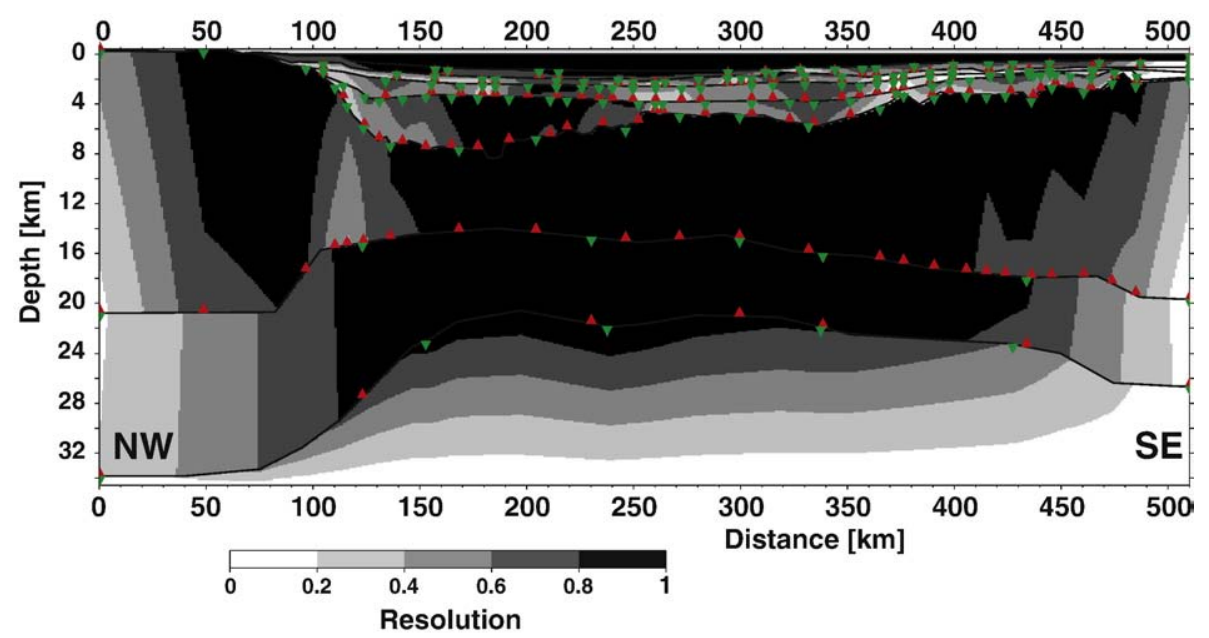

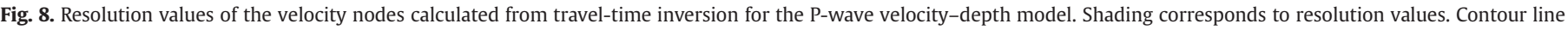

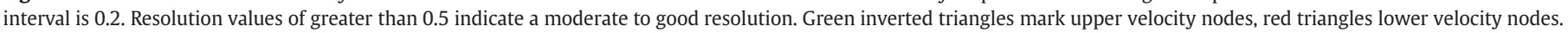
(For interpretation of the references to color in this figure legend, the reader is referred to the web version of this article.)

of line AWI-20030001. The crustal thickness approximately doubles between the shelf-break and the northwestern end of the line. Onshore within the southern South Island there are few constraints on crustal thickness and most estimates must be derived from either the central South Island region (e.g. 20-40 km) (Scherwath et al., 2003; Van Avendonk et al., 2004) or along the SESI seismic reflection line approximately $20 \mathrm{~km}$ east of the central and southern South Island coastline (Godfrey et al., 2001; Mortimer et al., 2002). This latter line lies within the near-shore zone of major northwest-southeast crustal thinning (Fig. 4) limiting its value as a constraint. The velocity model of Godfrey et al. (2001) has a crustal thickness of $\sim 30 \mathrm{~km}$ at the intersection with line AWI-20030001. Unfortunately, the gravity model in Mortimer et al. (2002), along the SESI line, has omitted the Moho. Their figure of crustal thickness variation is very similar to that of Godfrey et al. (2001) and may be based upon that work. At the southeastern line crustal thickness surface-wave dispersion studies (Adams, 1962) indicate an average crustal thickness for the Campbell Plateau of $17-23 \mathrm{~km}$. The wide-angle reflection and refraction model along line AWI-20030001 indicate a thickness of at least $23 \mathrm{~km}$ at the southeastern end of the line.

\section{Description of model}

The refraction seismic P-wave velocity-depth model (Fig. 7) shows four layers above the basement that have little lateral velocity variation except for the second from top layer. Parts of the layer

Table 1

Statistics of linear travel-time inversion for all phases within a particular modeling layer of the P-wave velocity-depth model.

\begin{tabular}{lllc}
\hline Phase & rms-misfit $[\mathrm{s}]$ & Chi-squared value & Number of picks \\
\hline $\mathrm{P}_{\text {dir }}$ & 0.030 & 0.439 & 447 \\
$\mathrm{P}_{\text {sed1 }}$ & 0.071 & 2.290 & 287 \\
$\mathrm{P}_{\text {sed } 1} \mathrm{P}$ & 0.154 & 2.473 & 32 \\
$\mathrm{P}_{\text {sed2 }} \mathrm{P}_{\text {sed3 }}$ & 0.092 & 2.027 & 977 \\
$\mathrm{P}_{\text {sed2 }} \mathrm{P}$ & 0.128 & 1.735 & 131 \\
$\mathrm{P}_{\text {sed3 }} \mathrm{P}$ & 0.102 & 0.876 & 346 \\
$\mathrm{P}_{\text {sed4 }}$ & 0.111 & 1.926 & 1854 \\
$\mathrm{P}_{\text {bas }} \mathrm{P}$ & 0.158 & 2.946 & 225 \\
$\mathrm{P}_{\text {g1 }}$ & 0.174 & 2.450 & 7364 \\
$\mathrm{P}_{\mathrm{g} 2}$ & 0.195 & 2.940 & 1582 \\
$\mathrm{P}_{\mathrm{c}} \mathrm{P}$ & 0.153 & 1.509 & 744 \\
$\mathrm{P}_{\mathrm{m}} \mathrm{P}$ & 0.169 & 1.782 & 4257 \\
$\mathrm{P}_{\mathrm{n}}$ & 0.168 & 1.732 & 1343 \\
\hline
\end{tabular}

interfaces are constrained by wide-angle reflections marked as bold lines. The uppermost layer has velocities ranging from $1.7 \mathrm{~km} / \mathrm{s}$ at the top to $2.5 \mathrm{~km} / \mathrm{s}$ at its base, with a maximum thickness of $0.75 \mathrm{~km}$, the second layer range from $2.3 \mathrm{~km} / \mathrm{s}$ to $3.1 \mathrm{~km} / \mathrm{s}$ at the base, with a maximum thickness of $0.9 \mathrm{~km}$. However, in the area between $245 \mathrm{~km}$ and $260 \mathrm{~km}$ at $750-1000 \mathrm{~m}$ depth (b.s.f.), the basal velocities are significantly increased to 3.8 to $4.0 \mathrm{~km} / \mathrm{s}$. Turning rays of three OBS stations cover this area.

The third layer from top has velocities of 2.5 to $3 \mathrm{~km} / \mathrm{s}$ at the top of the layer and 3.0 to $4.0 \mathrm{~km} / \mathrm{s}$ at its base and a maximum thickness of $1.1 \mathrm{~km}$. P-wave velocities in the area of $245 \mathrm{~km}$ to $260 \mathrm{~km}$ are in the same range, thus producing a velocity inversion in this area. Seismic velocities in the fourth layer from top range from $3.8 \mathrm{~km} / \mathrm{s}$ to $4.4 \mathrm{~km} / \mathrm{s}$ at its top and from 4.4 to $4.9 \mathrm{~km} / \mathrm{s}$ at the bottom of the layer. At 100$130 \mathrm{~km}$ (flank of Great South Basin) and 420-440 km (Pukaki Rise), velocities are significantly higher. The reason for the higher velocities at the flank of the Great South Basin may be that basement is shallower than predicted by the used depth-to-basement data. However, steep flanks and a moderate data cover do not allow an exact discrimination between basement and lowermost sediments. At the Pukaki Rise, increased velocities could be caused by the intrusions that can be seen in the potential field model.

The upper crustal layer has velocities from $5.0 \mathrm{~km} / \mathrm{s}$ to $5.5 \mathrm{~km} / \mathrm{s}$ at its top and $6.5 \mathrm{~km} / \mathrm{s}$ to $7.1 \mathrm{~km} / \mathrm{s}$ at the base. Velocities derived from data of one sonobuoy (Davey, 1977) northeast of the Pukaki Rise are $6.6 \mathrm{~km} / \mathrm{s}$ for the basement. This value seems to be too high and may be due to the sonobuoy's unreversed nature. Velocities of the lower crustal layer are between $6.6 \mathrm{~km} / \mathrm{s}$ and $7.1 \mathrm{~km} / \mathrm{s}$ at the top and $7.5 \mathrm{~km} /$ $\mathrm{s}$ at its bottom. Again, in this layer seismic velocities increase from NW to SE. The thickness of the crystalline crust totals $30 \mathrm{~km}$ beneath the coastline of South Island, $13 \mathrm{~km}$ beneath Great South Basin, and $24 \mathrm{~km}$ beneath the central Campbell Plateau. $P_{n}$ phases constrain a velocity of $7.6-7.7 \mathrm{~km} / \mathrm{s}$ in the uppermost mantle.

The gravity model assumes a crustal thickness of the South Island and the central Campbell Plateau (Cook et al., 1999) and is confirmed by refraction solutions for the top and base of the crust. The model crust is thinned beneath the entire Great South Basin, with a sharp increase in thickness towards the South Island northwest of $140 \mathrm{~km}$. Traversing southeast onto the Pukaki Rise, the increase of modelled crustal thickness is gentler in comparison. A small number of anomalies with a wavelength of $\sim 20 \mathrm{~km}$ over the central Campbell Plateau can be modelled by variations in the basement-depth that can be tentatively traced in the MCS section as well. 
The long-wavelength anomaly system of the magnetic anomaly pattern 200 nT beneath the Great South Basin (Fig. 4) can be modelled by an elongated magnetic body at $\sim 8 \mathrm{~km}$ depth (b.s.f.). The two magnetic anomalies near the Pukaki Rise can be well modelled by two small-scale ( $\sim 5 \mathrm{~km}$ wide) dike-like intrusions. In the MCS profile, two patches of reflections can be seen coinciding with these magnetic anomalies at $1.8 \mathrm{~s}$ (TWT) (Fig. 4). As the magnetic profile extends $33 \mathrm{~km}$ further than the MCS profile, the short-wavelength, low-amplitude structures at the Pukaki Rise cannot be found in the MCS data.

\section{Discussion}

\subsection{Shallow structure}

A high-velocity structure of $15 \mathrm{~km}$ horizontal extent was modelled in the second layer below the seafloor at $\sim 250 \mathrm{~km}$. The velocity of this area reaches $4.0 \mathrm{~km} / \mathrm{s}$ at $750-1000 \mathrm{~m}$ depth (b.s.f.) compared to Pwave velocities of $2.7-3.0 \mathrm{~km} / \mathrm{s}$ in the lateral vicinity. The highvelocity structure is constrained by three OBS recordings that also show strong indication for a velocity inversion (i.e. travel time stepback). In the MCS section, a region of increased amplitudes and decreased reflector continuity coincides well with the high-velocity body of the seismic refraction model. The top reflector interpreted from this area correlates with the top of Eocene reflector on other profiles (e.g. F-14 and B-218) (Cook et al., 1999). Salt, an intrusion or apron sediments could cause a zone of high-velocities in this area. Salt would cause higher velocities of $\sim 4 \mathrm{~km} / \mathrm{s}$, but a salt body would have a rather diffuse pattern of low-amplitude internal reflections. Moreover, no large occurrences of salt have been reported previously in the Great South Basin (Cook et al., 1999). Apron sediments could have been deposited by channel-like features like those mentioned by Cook et al. (1999) and observed in the MCS data (Fig. 4). Higher compaction, or a different grain size, could likely cause the observed high-velocity lens. Similar velocities for clastic apron sediments were reported, for example, by Grevemeyer et al. (2001). A depositional feature would also be consistent with the moderately chaotic reflection patterns.

A magmatic intrusion could be another possible reason for the high-velocity zone. The P-wave velocities of max. $4 \mathrm{~km} / \mathrm{s}$ in this region would be very low for intrusive rocks, but the magnetic profile shows a broad low-amplitude positive anomaly of 30-35 km wavelength over this part of the profile. Although this long-wavelength character speaks in favour of a somewhat deeper source, with the level of the high-velocity zone in MCS data is consistent with the interpretation of the Foveaux volcanic sediments of dating to Late Eocene-Miocene times (Carter, 1988b). However, magnetic anomalies observed here are $\sim 180 \mathrm{~km}$ southeast of the Foveaux volcanic sediment province. In summary, the observations of this high-velocity structure are too ambiguous to make a clear interpretation of its origin, but on the basis of the seismic velocities, we favour interpreting this structure as a sedimentary feature.

\subsection{Crustal structure}

Reflections from the Moho, as well as the gravity model, indicate a very thin $(\sim 13 \mathrm{~km})$ crystalline crust beneath the Great South Basin in contrast to the $30 \mathrm{~km}$ thickness beneath the coastline of the South Island and $22 \mathrm{~km}$ beneath the central Campbell Plateau (Fig. 7). The modelled crystalline crustal thickness (without sediments) beneath the Great South Basin compares very well with that suggested by Cook et al. (1999), while our crystalline crustal thickness of the central Campbell Plateau is slightly $(\sim 2 \mathrm{~km})$ less than that of Cook et al. (1999). The total crustal thickness with sediments $(27 \mathrm{~km})$, and velocity structure $\left(v_{\mathrm{p}}=5.5-6.8 \mathrm{~m} / \mathrm{s}\right)$ of the upper crystalline crust of the Campbell Plateau indicate very strongly that this crust is of continental origin (compare e.g. Christensen and Mooney, 1995).
Collins (1991) derived an average total crustal thickness of 30$45 \mathrm{~km}$ for continental crust in Australia. This crust is mainly undeformed, has similar lithologic characteristics to the crust in New Zealand and was adjacent to it in Cretaceous time. A similar prebreakup crustal thickness is assumed for the Ross Sea, which was also adjacent to the Campbell Plateau (Trey et al., 1999). If, using similar assumptions to that of Bradshaw (1989), we assume a thickness prior to deformation of 35-40 km for the Campbell Plateau crust, we would thus calculate stretching factors of $1.6-1.8$ for the central Campbell Plateau and 2.7-3.0 for the Great South Basin. If, on the other hand, the Campbell Plateau already had its present thickness prior to Great South Basin formation, then stretching factors of the Great South Basin would be $\sim 2$. Considering the pre-stretching thickness of the Great South Basin to have been the same as that of the central Campbell Plateau, the unstretched Great South Basin would have had a width along this profile of $\sim 75 \mathrm{~km}$ compared to $\sim 150 \mathrm{~km}$ today.

The crustal thickness beneath the coast of the South Island of New Zealand corresponds well to the thickness modelled by Scherwath et al. (2003). Throughout the profile, we observe crustal velocities from 5.5 to $6.6 \mathrm{~km} / \mathrm{s}$ in the upper crust, except beneath Pukaki Rise, where the velocities are slightly higher at 5.5 to $7.1 \mathrm{~km} / \mathrm{s}$. The observed velocities are, in the upper crust, slightly higher $(0.2 \mathrm{~km} / \mathrm{s})$ than the velocities indicated by Scherwath et al. (2003). However, the seismic lines of the SIGHT experiment (Scherwath et al., 2003; Van Avendonk et al., 2004) extend into the Canterbury Basin rather than into the Great South Basin, so it is questionable whether their results for the Pacific end of the profile can be compared with the results of the line presented here.

\subsection{Underplating}

The significant increase in seismic velocities of the lower crust and the reflector at the top of the high-velocity body of the central Campbell Plateau suggest that this high-velocity lower crust could be caused by underplating (Figs. 7 and 9). Underplating has been described at various rifted passive margins, e.g. at the Rhine Graben (Wenzel et al., 1991; Mayer et al., 1997) or the Oslo Graben (Neumann et al., 1992; Pedersen and van der Beek, 1994). At the Oslo Graben, Pedersen and van der Beek (1994) present evidence for a $\sim 25 \mathrm{~km}$ thick crystalline crust in parts of their profiles. The lower part of this crust has high $(<7.1 \mathrm{~km} / \mathrm{s})$ P-wave velocities, similar to those on our findings $(7.2-7.4 \mathrm{~km} / \mathrm{s})$. In the Rhine Graben, Mayer et al. (1997) show an underplated body with velocities of $<6.6 \mathrm{~km} / \mathrm{s}$ at the base of a crust of similar thickness. The top of this underplating is constrained by a distinct mid-crustal reflector. Although underplating is often attributed to extensive volcanism (e.g. seawarddipping reflectors at the U.S. Atlantic margin Holbrook et al., 1994) volcanism does not necessarily have to be extensive (e.g. Rhine Graben, Larroque et al., 1987; Wenzel et al., 1991). To a lesser extent, intraplate volcanism (Adams, 1981; Hoernle et al., 2006), extrusive volcanism (Cook et al., 1999) and shallow diking at the Pukaki Rise (this work) has been observed. However, we do not have control over the relative timing of the underplating. It could possibly be related to extension in Great South Basin and Bounty Trough. Then it would be $83 \mathrm{Ma}$ and older, while volcanism is mainly of Cenozoic origin (Cook et al., 1999, Hoernle et al., 2006). If such a $6 \mathrm{~km}$ thick underplate exists beneath the entire Campbell Plateau, as defined by the $1000 \mathrm{~m}$ isobath, its volume totals $\sim 2,500,000 \mathrm{~km}^{3}$. If just the central Campbell Plateau, confined by the $750 \mathrm{~m}$ isobath, was underplated, the volume would be $\sim 1,000,000 \mathrm{~km}^{3}$. Our profile covers only parts of the Campbell Plateau, so the estimate of the volume of underplating is based on an extrapolation and states maximum values.

\subsection{Comparison with SIGHT results}

In the southeastern part of our profile ( $260 \mathrm{~km}-430 \mathrm{~km}$, below the central Campbell Plateau), we observe strong intra-crustal reflections 


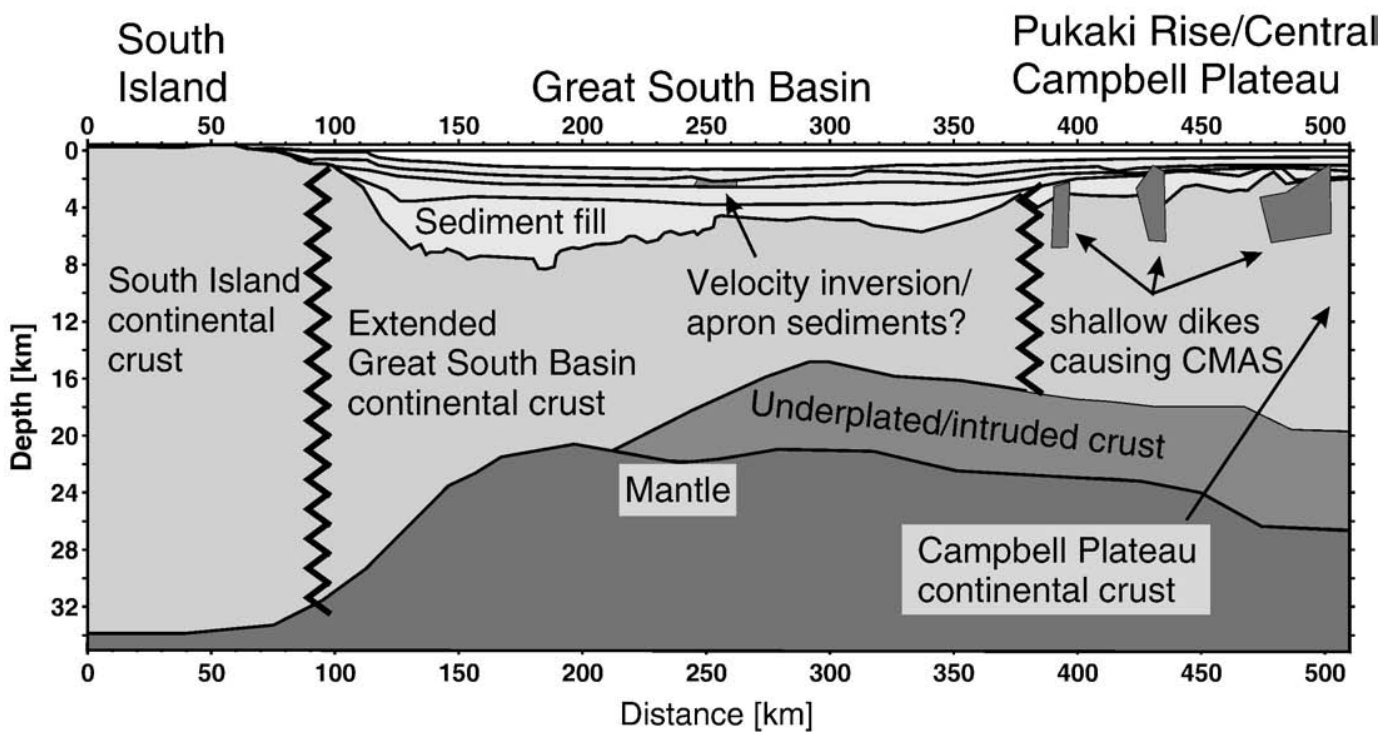

Fig. 9. Interpretative sketch of profile AWI-20030001/AWI-20030013. Area between zigzagged lines is the approximate area of extended continental crust of Great South Basin.

from the boundary between upper and lower crust. This reflector lies $\sim 6 \mathrm{~km}$ above the Moho reflector. Scherwath et al. (2003) and Van Avendonk et al. (2004) reported an intra-crustal reflector at the same depth beneath the Canterbury Basin from the SIGHT profiles. Such mid-crustal reflectors are not observed beneath the Great South Basin. The observation of this reflector beneath the central Campbell Plateau coincides with a lateral increase in P-wave velocities of the lower crust by $\sim 0.3-0.4 \mathrm{~km} / \mathrm{s}$, whereas P-wave velocities beneath the Canterbury Basin are not increased (Scherwath et al., 2003; Van Avendonk et al., 2004). E.g. Smith et al. (1995), Scherwath et al. (2003), and Van Avendonk et al. (2004) interpreted the lower crust beneath the Canterbury Basin as old oceanic crust overlain by Caples and Torlesse metasedimentary rocks. Adopting this earlier interpretation of the mid-crustal reflector for the Campbell Plateau would mean that the northwestern Campbell Plateau was underlain by oceanic crust. We found no evidence for oceanic crust beneath the Great South Basin, neither in the seismic velocity field nor in the reflection patterns. Drill sites in the Great South Basin, e.g. sites Tara- 1 and Pakaha- 1 , found gneiss or granite at the upper surface of the basement (Cook et al., 1999). However, the profile presented in this work lies close to the inferred suture zone suggested by Cook et al. (1999) and Davey (2005), which is coincident with the Median Batholith. Thus it seems possible that our profile crosses the MTZ depending on its offshore continuation and would then not be comparable with the results of the SIGHT lines. The offshore continuation of the Median Batholith (Cook et al., 1999; Davey, 2005) runs southwards of our profile near the coast and seems to intersect it at the transition from Great South Basin to Campbell Plateau which coincides with the onset of the CMAS (Figs. 1 and 3). However, in this part of the profile, there is no evidence for an abrupt change in the structure of the crust. This observation suggests that the profile does not run in the Median Batholith, but entirely in the Murihiku/Brook Street Terrane. Velocities at the intersection with the profile of Godfrey et al. (2001) are similar on both profiles, suggesting that Murihiku Terrane extends at least into the Great Basin along our profile. This would support the assumption that our profile is on the same side of the suture zone as the Canterbury Region.

Velocities of the uppermost mantle beneath the Great South Basin are rather low with ca. $7.7 \mathrm{~km} / \mathrm{s}$. Similarly low mantle velocities in the SIGHT region nearby have been interpreted as thermal perturbations in the upper mantle (Hoke et al., 2000; Godfrey et al., 2001). Unfortunately, the profile of Godfrey does not have upper mantle velocities at the cross-point of the two profiles.

\subsection{Origin of CMAS and SMAS}

If the CMAS and the shallow dike-like structure which seem to be the cause of the CMAS (Fig. 4) are attributed to the underplated body, then they do not coincide with it completely in terms of location (Fig. 9). The northwestward limit of the CMAS is at $380 \mathrm{~km}$ along the profile, while the high velocities begin at $\sim 300 \mathrm{~km}$ (Figs. 4 and 7 ). The CMAS differs from the SMAS in displaying shorter wavelengths. Interpretations vary as to how far the CMAS and the SMAS can be interpreted as dextrally-offset parts of the same anomaly system (Davey and Christoffel, 1978; Sutherland, 1999). The high-frequency parts of the CMAS along our magnetic profile can be modelled by shallow dike-like structures. Two coincident positive free-air gravity anomalies additionally indicate intrusions or shallow basement highs to be present. Due to the data quality of the MCS section, it is not possible to distinguish between these two possibilities. As the MCS section does not continue over Pukaki Rise (Fig. 4) dating of these intrusional structures by means of seismic data is not possible. Rock samples dredged from the Pukaki Rise yield ages up to $4.3 \mathrm{Ma}$ (R. Werner, pers. comm., 2006). We cannot rule out that this younger magmatic activity may be related to underplating beneath the Campbell Plateau. The implied differences in magmatic activity and the observed variability in the style of the magnetic and associated gravity anomalies (Fig. 3) suggest that either the sources of the CMAS and SMAS have different origins, or that they were modified in different ways following strike-slip separation proposed by Davey and Christoffel (1978). Indeed, a recent reconstruction of Grobys et al. (2008) suggests that CMAS and SMAS did not experience the previously indicated strike-slip separation.

It is unclear why the proposed underplating would occur only beneath the Campbell Plateau but not beneath the Great South Basin, as this is the thinnest and weakest part of this region off southeastern New Zealand. One explanation would be that the underplating was related to an extensional event that took place prior to the Great South Basin opening. Most continental rift systems (e.g. Diepr-DonetskBasin, East African Rift System or Bounty Trough) (Ebinger and Casey, 2001; Grobys et al., 2007; The DOBREfraction'99 Working Group et al., 2003) show underplating and/or intrusions at the rift axis, whereas underplating along our profile is interpreted beneath the flanks of the rift system. This phenomenon has been observed at only a very few other rift systems: The Hebrides Shelf in the vicinity of the volcanic northeastern Rockall Trough (Klingelhöfer et al., 2005) is underlain by 
a $\sim 6 \mathrm{~km}$ thick underplate, whereas the seaward Rockall Trough itself consists of extended continental crust that has a thickness of between 12 and $\sim 19 \mathrm{~km}$ and no underplate, similar to the Great South Basin. Klingelhöfer et al. (2005) did not remark on this arrangement.

Most recent plate-tectonic reconstructions suggest that the Campbell Plateau, Lord Howe Rise, the Challenger Plateau and the Ross Sea were adjacent prior to the late Gondwana break-up (e.g. Wandres and Bradshaw, 2005). All these regions show similar crustal thickness (Sundaralingham and Denham, 1987; Trey et al., 1999; Wood and Woodward, 2002). Underplating is interpreted to have occurred beneath Lord Howe Rise and the Challenger Plateau (Wood and Woodward, 2002), and the crust of the Ross Sea is interpreted to be intruded by mafic rocks (Trey et al., 1999). For this reason, we assume that crustal thinning and underplating beneath the four formerly adjacent areas are related to one event, which we identify as Early Cretaceous or Jurassic thinning prior to the break-up (Uruski and Wood, 1991; Wood, 1993). Consistent with this, Sutherland (1999) relates the source of the CMAS and SMAS either to Median Tectonic Zone volcanism at $\sim 130 \mathrm{Ma}$ (Kimbrough et al., 1994) or to even older volcanic arc related rocks. The reconstructions of Fitzgerald (2002) and Wandres and Bradshaw (2005), based on New Zealand and Antarctic tectonostratigraphy, indicate an extensional phase in the vicinity of these submarine plateaux in the Early Cretaceous at $\sim 120$ Ma. Forster and Lister (2003) proposed a first extension in the South Island at $\sim 110 \mathrm{Ma}$ from onshore geology. With the data presented here, it is not possible to discriminate between these events or refine the proposed timing.

\section{Conclusion}

The CAMP reflection/refraction seismic profiling and gravity/ magnetic survey and ensuing modelling have revealed much about the extensional structures of the Campbell Plateau. Quantification of the crustal extension during Cretaceous Great South Basin opening will help in refining plate-kinematic reconstructions of the southwestern Pacific. This first combined refraction/wide-angle reflection and MCS survey across a large part of the Campbell Plateau provides new detailed information about the Campbell Plateau extension and the timing of this extension. Our main observations and interpretations are:

1) The Moho shallows from $33 \mathrm{~km}$ (b.s.f.) beneath the coast of the South Island to $21 \mathrm{~km}$ (b.s.f.) underneath the Great South Basin. It deepens again to $27 \mathrm{~km}$ under the central Campbell Plateau.

2) In the P-wave model, a high-velocity body in the lower crust can be observed beneath the central Pukaki Rise. The velocities of this body gently rise towards the central Campbell Plateau. The boundary between the upper and lower crust is highly reflective beneath the Campbell Plateau, while this mid-crustal reflector does not occur beneath the Great South Basin or the coast of the South Island.

3) P-wave velocities in the lower crust rise from $6.7-7.1 \mathrm{~km} / \mathrm{s}$ under the South Island and the Great South Basin to $7.1-7.4 \mathrm{~km} / \mathrm{s}$ beneath the Pukaki Rise. In the upper crust, P-wave velocities range from $5.1-6.5 \mathrm{~km} / \mathrm{s}$ beneath the South Island to $5.8-7.0 \mathrm{~km} / \mathrm{s}$ under the Pukaki Rise. Four sedimentary layers in the Great South Basin could be recognized in the refraction/wide-angle reflection record, with velocities in the ranges $1.7-2.5 \mathrm{~km} / \mathrm{s}, 2.3-3.1 \mathrm{~km} / \mathrm{s}, 2.5-4.0 \mathrm{~km} / \mathrm{s}$ and $3.8-5.8 \mathrm{~km} / \mathrm{s}$.

4) The long-wavelength free-air gravity anomaly of the Great South Basin has a positive amplitude of $\sim 40$ mgal. It can be modelled by crustal thickness variations. Across the Campbell Plateau, a number of anomalies with wavelengths of $\sim 20 \mathrm{~km}$ and positive amplitudes of $\sim 200$ mgal can be related to shallow basement structures.

5) The high-velocity body beneath the northwestern Campbell Plateau is interpreted as an underplated body with a possible maximum volume of $\sim 1.0-2.5 \times 10^{6} \mathrm{~km}^{3}$. The high P-wave velocities of this body, the fact that it is enclosed by prominent reflectors and comparisons with formerly adjacent submarine plateaus are strong indications of an underplated continental crust. The reduced crustal thickness of the Great South Basin compared to Campbell Plateau indicates a stretching factor of $\sim 2$. If we assumed instead that both features formed by stretching of crust with an initial thickness of 35-40 km yields a $\beta$-factor of 2.7-3.0 for the Great South Basin and 1.6-1.8 for the Campbell Plateau.

6) The CMAS differs significantly from the SMAS in wavelength. The CMAS correlates with short-wavelength gravity anomalies, and may be associated with underplating and shallow dike-like (Figs. 4 and 9) structures beneath the central Campbell Plateau. It seems most likely that the two magnetic anomaly systems have different origins and/or developing histories. Rock samples dredged from the seafloor suggest ongoing magmatic activity that persisted at least into Pliocene time. Underplating occurred underneath the northwestern Campbell Plateau but not beneath the Great South Basin and is also thought to have affected neighbouring plateaus like the Lord Howe Rise and Challenger Plateau. This extension and underplating may have occurred at the same time, when all the plateaus were adjacent probably in the Early Cretaceous at $~ 135$ 110 Ma or even in Jurassic time.

\section{Acknowledgements}

We are grateful to the captain and crew of R/V Sonne during cruise SO-169 for their support and assistance. This project is primarily funded by the German Federal Ministry of Education and Research under BMBF contract no. 03G0169A as well as through contributions from AWI and GNS. The German Academic Exchange Fund (DAAD) funded a visit of J.G. to GNS for two months. Furthermore, we thank GeoPro GmbH (Hamburg) for their support in providing and operating the OBS equipment and Exploration Electronics Ltd. (Norwich) for providing and operating the seismic streamer. We had useful discussions with Reinhard Werner, Rupert Sutherland and Nick Mortimer. We thank Martin Scherwath, Harm van Avendonk and Richard Hobbs for their reviews. Graeme Eagles greatly improved this manuscript. Most of the figures were generated with Generic Mapping Tools (Wessel and Smith, 1998). This is AWI contribution no awi-n17143.

\section{References}

Adams, R.D., 1962. Thickness of the Earth's crust beneath the Campbell Plateau. New Zealand Journal of Geology and Geophysics 5, 74-85.

Adams, C.J., 1981. Migration of late Cenozoic volcanism in the South Island of New Zealand and the Campbell Plateau. Nature 294, 153-155.

Beggs, J.M., 1993. Depositional and tectonic history of the Great South Basin. In: Ballance, P.F. (Ed.), South Pacific Sedimentary Basins. Elsevier Science Publishers B.V. Amsterdam, pp. 365-373.

Berndt, C., Mjelde, R., Planke, S., Shimamura, H., Faleide, J.I., 2001. Controls on the tectono-magmatic evolution of a volcanic transform margin: the Vøring Transform Margin, NE Atlantic. Marine Geophysical Researches 22, 133-152.

Bradshaw, J.D., 1989. Cretaceous geotectonic patterns in the New Zealand region. Tectonics 8 (4), 803-820.

Carter, R.M., 1988a. Plate boundary tectonics, global sea-level changes and the development of the eastern South Island continental margin, New Zealand, Southwest Pacific. Marine and Petroleum Geology 90-107 5(May).

Carter, R.M., 1988b. Post breakup stratigraphy (Kaikoura Synthem: Cretaceous Cenozoic) of the continental margin of southeastern New Zealand. New Zealand Journal of Geology and Geophysics 31, 405-429.

Christensen, N.I., Mooney, W.D., 1995. Seismic velocity structure and composition of the continental crust: a global view. Journal of Geophysical Research 100 (B7), 9761-9788.

Collins, C.D.N., 1991. The nature of the crust-mantle boundary under Australia from seismic evidence. In: Drummond, B.J. (Ed.), The Australian Lithosphere. Geological Society of Australia, pp. 67-80. special publication.

Cook, R.A., Sutherland, R., Zhu, H., Funnel, R., Killops, S.D., 1999. Cretaceous-Cenozoic Geology and Petroleum Systems of the Great South Basin, New Zealand. Institute of Geological and Nuclear Sciences monograph, 20. Institute of Geological and Nuclear Sciences Limited, Lower Hutt, New Zealand. 188 pp.

Cooper, R.A., 1989. Early Paleozoic terranes of New Zealand. Journal of the Royal Society of New Zealand 19 (1), 73-112. 
Cooper, A.K.C., 2004. New Zealand Geological Timescale 2004/2 wallchart. Institute of Geological and Nuclear Science information series, 64.

Cooper, R.A., Tulloch, A.J., 1992. Early Palaeozoic terranes in New Zealand and their relationship to the Lachlan Fold Belt. Tectonophysics 214,129-144.

Davey, F.J., 1977. Marine seismic measurements in the New Zealand Region. New Zealand Journal of Geology and Geophysics 20 (4), 719-777.

Davey, F.J., 2005. A Mesozoic crustal suture on the Gondwana margin in the New Zealand region. Tectonics 24. doi:10.1029/2004TC00171.

Davey, F.J., Christoffel, D.A., 1978. Magnetic anomalies across Campbell Plateau, New Zealand. Earth and Planetary Science Letters 41, 14-20.

Eagles, G., Gohl, K., Larter, R.D., 2004. High-resolution animated tectonic reconstruction of the South Pacific and West Antarctic Margin. Geochemistry, Geophysics, Geosystems 5, Q07002. doi:10.1029/2003GC000657.

Ebinger, C.J., Casey, M., 2001. Continental breakup in magmatic provinces: an Ethiopian example. Geology 29 (6), 527-530.

Farrar, E., Dixon, J.M., 1984. Overriding of the Indian-Antarctic Ridge: origin of Emerald Basin and migration of the late Cenozoic Volcanism in southern New Zealand and Campbell Plateau. Tectonophysics 104, 243-256.

Fitzgerald, P., 2002. Tectonics and landscape evolution of the Antarctic plate since the breakup of Gondwana, with an emphasis on the West Antarctic Rift System and the Transantarctic Mountains. Royal Society of New Zealand Bulletin 35, 453-469.

Forster, M.A., Lister, G.S., 2003. Cretaceous metamorphic core complexes in the Otago Schist, New Zealand. Australian Journal of Earth Sciences 50. doi:10.1046/j.14400952.2003.00986.x

Godfrey, N.J., Davey, F.J., Stern, T., Okaya, D., 2001. Crustal structure and thermal anomalies of the Dunedin Region, South Island, New Zealand. Journal of Geophysical Research 106 (B12), 30835-30848.

Grevemeyer, I., Weigel, W., Schüssler, S., Avedik, F., 2001. Crustal and upper mantle seismic structure and lithospheric flexure along the Society Island hotspot chain. Geophysical Journal International 147 (1), 123-140.

Grobys, J.W.G., et al., 2007. Is the Bounty Trough, off southeastern New Zealand an aborted rift? Journal of Geophysical Research 112, B03103. doi:10.1029/ 2005JB004229.

Grobys, J.W.G., Gohl, K., Eagles, G., 2008. Crustal balancing applied for plate-tectonic reconstruction of Zealandia. Geochemistry, Geophysics, Geosystems 9, Q01005 doi:10.1029/2007GC001691.

Hoernle, K., et al., 2006. Cenozoic intraplate volcanism on New Zealand: upwelling induced by lithospheric removal. Earth and Planetary Science Letters 248 (1-2). doi:10.1016/j.epsl.2006.06.001.

Hoke, L., Poreda, R., Reay, A., Weaver, S.D., 2000. The subcontinental mantle beneath southern New Zealand, characterised by helium isotopes in intraplate basalts and gas-rich springs. Geochima Cosmochima Acta 64, 2489-2507.

Holbrook, W.S., et al., 1994. Deep Structure of the U.S. Atlantic continental margin, offshore South Carolina, from coincident ocean bottom and multichannel seismic data. Journal of Geophysical Research 99 (B5), 9155-9178.

Hunt, T., 1978. Stokes magnetic anomaly system. New Zealand Journal of Geology and Geophysics 21 (5), 595-606.

Kamp, P.J.J., 1986. Late Cretaceous-Cenozoic tectonic development of the Southwest Pacific Region. Tectonophysics 121, 225-251.

Kimbrough, D.L., et al., 1994. Uranium-lead zircon ages from the Median Tectonic Zone, New Zealand. New Zealand Journal of Geology and Geophysics 37, 393-419.

Klingelhöfer, F., Edwards, R.A., Hobbs, R.W., England, R.W., 2005. Crustal structure of the NE Rockall Trough from wide-angle seismic data modeling. Journal of Geophysical Research 110, B11105. doi:10.1029/2005JB003763.

Larroque, J.M., Etchecopar, A., Philip, H., 1987. Evidence for the permutation of stresses $s_{1}$ and $s_{2}$ in the Alpine foreland: the example of the Rhine Graben. Tectonophysics $144,315-322$.

Mayer, G., et al., 1997. The deep crust of the Southern Rhine Graben: reflectivity and seismicity as images of dynamic processes. Tectonophysics $275,15-40$.

Mortimer, N., et al., 1999. Overview of the Median Batholith, New Zealand: a new interpretation of the geology of the Median Tectonic Zone and adjacent rocks. Journal of African Earth Sciences 29 (1), 257-268.
Mortimer, N., Davey, F.J., Melhuish, A., Yu, J., Godfrey, N.J., 2002. Geological interpretation of a deep seismic reflection profile across the Eastern Province and Median Batholith, New Zealand: crustal architecture of an extended Phanerozoic convergent orogen. New Zealand Journal of Geology and Geophysics 45, 349-363.

Neumann, E.-R., Olsen, K.H., Baldrige, W.S., Sundvoll, B., 1992. The Oslo Rift: a review. Tectonophysics 208, 1-18.

Pedersen, T., van der Beek, P., 1994. Extension and magmatism in the Oslo Rift, southeast Norway: no sign of a mantle plume. Earth and Planetary Science Letters 123, 317-329.

Sandwell, D.T., Smith, W.H.F., 1997. Global seafloor topography from satellite altimetry and ship depth soundings. Science 277, 1956-1962.

Scherwath, M., et al., 2003. Lithospheric structure across oblique continental collision in New Zealand from wide-angle P wave modeling. Journal of Geophysical Research 108 (B12), 2566. doi:10.1029/2002JB002286.

Smith, W.H.F., Sandwell, D.T., 1997. Marine gravity anomaly from Geosat and ERS 1 satellite altimetry. Journal of Geophysical Research 102 (B5), 10039-10054.

Smith, E.G.C., Stern, T., O'Brien, B., 1995. A seismic velocity profile across the central South Island, New Zealand, from explosion data. New Zealand Journal of Geology and Geophysics 38, 565-570.

Sundaralingham, K., Denham, D., 1987. Structure of the upper mantle beneath the Coral and Tasman Seas, as obtained from group and phase velocities of Rayleigh waves. New Zealand Journal of Geology and Geophysics 30, 329-341.

Sutherland, R., 1999. Basement geology and tectonic development of the greater New Zealand region: an interpretation from regional magnetic data. Tectonophysics 308 . doi:10.1016/S0040-1951(99)00108-0.

The DOBREfraction'99 Working Group, et al., 2003. "DOBREfraction '99" - velocity model of the crust and upper mantle beneath the Donbas Foldbelt (East Ukraine). Tectonophysics 371, 81-110.

Trey, H., et al., 1999. Transect across the West Antarctic rift system in the Ross Sea, Antarctica. Tectonophysics 301, 61-74.

Uruski, C., Wood, R., 1991. A new look at the New Caledonia Basin, an extension of the Taranaki Basin, offshore North Island, New Zealand. Marine and Petroleum Geology 8 (11), 379-391.

Van Avendonk, H.J.A., et al., 2004. Continental crust under compression: a seismic refraction study of South Island Geophysical Transect I, South Island, New Zealand. Journal of Geophysical Research 109, B06302. doi:10.1029/2003JB002790.

Wandres, A.M., Bradshaw, J.D., 2005. New Zealand tectonostratigraphy and implications from conglomeratic rocks for the configuration of the SW Pacific margin of Gondwana. Geological Society Special Publication 246, 179-216.

Wenzel, F., Brun, J.-P., ECORS-DECORP working group, 1991. A deep reflection seismic line across the Northern Rhine Graben. Earth and Planetary Science Letters 104, 140-150.

Wessel, P., Smith, W.H.F., 1998. New, improved version of Generic Mapping Tools released. EOS Transactions of the American Geophysical Union 79 (47), 579.

White, R.S., Matthews, D.H., 1980. Variations in oceanic upper crustal structure in a small area of the northeastern Atlantic. Geophysical Journal of the Royal Astronomical Society 61, 401-431.

Wood, R., 1993. The Challenger Plateau. In: Ballance, P.F. (Ed.), South Pacific Sedimentary Basins. Sedimentary Basins of the World, 2. Elsevier Science Publishers B.V., Amsterdam, pp. 351-364.

Wood, R., Woodward, D.J., 2002. Sediment thickness and crustal structure of offshore western New Zealand from 3-D gravity modelling. New Zealand Journal of Geology and Geophysics 45, 243-255.

Zelt, C.A., 1999. Modelling strategies and model assessment for wide-angle seismic travel time data. Geophysical Journal International 139, 183-204.

Zelt, C.A., Smith, R.B., 1992. Seismic travel time inversion for 2-D crustal velocity structure. Geophysical Journal International 108, 16-34. 